\title{
How to The Prospect of The Supply Chain Performance Stability and Implication of The Sustainability of Indonesia's Vanilla Origin Commodities?
}

\author{
Marthinus Boxy ${ }^{1}$, Nur Endah Retno Wuryandari ${ }^{2}$, Dudi Permana ${ }^{3}$ \\ $\left\{\right.$ logistic01boxy@gmail.com ${ }^{1}$,nurendah.retno@gmail.com², dudi.permana@mercubuana.ac.id $\left.{ }^{3}\right\}$ \\ Student of Universitas Mercu Buana, Jakarta ${ }^{1}$, Universitas Dian Nusantara, Jakarta ${ }^{2}$, Universitas Mercu \\ Buana, Jakarta ${ }^{3}$
}

\begin{abstract}
The movement of Indonesian vanilla commodity supply has a good impact, in the background, Indonesia is the second supplier after Madagascar. The purpose of this study is to evaluate the performance of the supply chain to improve and stabilize the supply chain of Indonesian vanilla commodities. Supply chain performance measurements are evaluated with the Analytical Hierarchy Process (AHP) compiled through the principle of Supply Chain Operation Reference (SCOR). The research sample of 11 respondents consisted of researchers/practitioners where we discussed brainstorming and weighting the questionnaire. Description of supply chain flow is analyzed based on the principle of Van Der Vorst, while the evaluation of supply chain performance through SCOR-AHP, also this study evaluates supply chain risk along with its priority implications. The results have expressed 3 supply chain sustainability policy schemes, namely agribusiness partnerships, bioprocess, and price stability. The scheme is applied to supply chain actors, namely farmers, collectors, and SMEs.
\end{abstract}

Keyword: Supply Chain Performance; SCOR-AHP; Agribusiness Policy; Bioprocess Policy; Price Stability Policy

\section{Introduction}

The importance of food supply while the development and innovation required to achieve optimization and sustainability. Achievement of agricultural development, according to the Minister of Agriculture of RI, Gross Domestic Product (GDP) maintains the 5th largest global

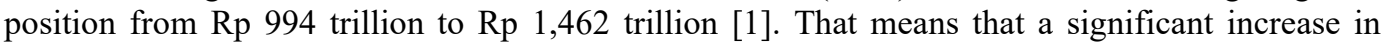
agricultural production in the country.

One excels at developing agricultural commodities is the spice commodity means vanilla. Vanilla from Indonesia has become the world's flagship, known as Java Vanilla Beans. Where the quality level can reach $2.75 \%$. It is superior to other vanilla export countries. The comparison of the drying quality of the moisture content is presented in table 1.

Table 1. Comparison of Vanilla Commodity Levels

\section{Country Level Test Results}




\begin{tabular}{cc} 
Indonesia & $2,75 \%$ \\
Madagascar & $1,91-1,98 \%$ \\
Tahiti & $1,55-2,02 \%$ \\
Mexico & $1,89-1,98 \%$ \\
Srilangka & $1,48 \%$ \\
\hline
\end{tabular}

Source: Data processed (2020)

Drying the vanilla commodity is processed through a fermentation stage starting from wet long pods to drying according to the moisture content level. A good water content level is also influenced by the geographical location of the cultivation. The best quality habitat for vanilla is in the latitude zone of 0-10 degrees. Meanwhile, Madagascar is at a latitude of 20 degrees south latitude and Indonesia stretches 6 degrees north to 11 south latitude [2]. In addition, the selling price of vanilla is getting better in the local market and the export market. The price of vanilla commodity is sold in the local market at IDR 5,000,000 per kilogram, while the export market reaches USD 600 per kilogram [3], this opportunity has the potential to increase the welfare of farmers in developing their agricultural investment in vanilla commodities. In addition, vanilla commodity exports increased from USD 14.41 million in 2015 to USD 62.08 million in the 2016 period [4].

Based on data from the Ministry of Trade of the Republic of Indonesia (Ministry of Trade), the realization of the trade in commodity types of spices in 2014 to 2018 (table 2)

Table 2. Realization of Export-Import of Indonesian Spice Commodities

\begin{tabular}{lrrrrr}
\hline Description & $\mathbf{2 0 1 4}$ & $\mathbf{2 0 1 5}$ & $\mathbf{2 0 1 6}$ & $\mathbf{2 0 1 7}$ & $\mathbf{2 0 1 8}$ \\
\hline Export & 1835.1 & 2196 & 1896.5 & 1964.7 & 1551.8 \\
Import & 671.7 & 458.2 & 541.2 & 704.5 & 793.6 \\
\hline
\end{tabular}

Source: Badan Pusat Statistik (2019)

The high export of spices is domained in the markets of Pakistan, Europe and other countries, while the level of enthusiasts for Indonesian vanilla exports is more in the domain of markets in Europe, America and other countries. This is predicted from the demand for vanilla to America to reach 8 tons per month [5]. In addition, there is a nickname that is unique to a commodity from Indonesia, namely Java Vanilla Beans, where there is a different flavor of vanilla which is used as a mixture of the restaurant and beverage industry [1].

The realization of the vanilla trade commodity from Indonesia is in second place. With a compound annual growth rate of $4.7 \%$ in the coming 2018 to 2027 [6]. In order to maintain and increase the glory of the world's vanilla commodity, this study aims to measure the supply chain performance of the vanilla farmer groups in Indonesia. Researchers assess and evaluate each performance attribute in the supply chain. This is at the same time to determine the method for increasing the ranking of Indonesian vanilla exports in the world class.

Table 3: Realization of Global Supply of Vanilla Commodities 


\begin{tabular}{cccccc}
\hline Country & $\mathbf{2 0 1 2}$ & $\mathbf{2 0 1 3}$ & $\mathbf{2 0 1 4}$ & $\mathbf{2 0 1 5}$ & $\mathbf{2 0 1 6}$ \\
\hline Madagascar & 10653 & 44671 & 118249 & 208470 & 408349 \\
Indonesia & 5367 & 7279 & 8512 & 17718 & 70859 \\
Mauritius & 945 & 1301 & 4795 & 22376 & 49028 \\
Germany & 17417 & 27160 & 31459 & 37629 & 45433 \\
France & 20124 & 29677 & 32389 & 32913 & 44384 \\
\hline
\end{tabular}

Sources: FAO statistics (2019)

\section{Literatur Review}

The formation of a supply chain aims to focus on collaboration and development of relationships between supply chain actors, namely suppliers and producers as well as consumers through evaluation of each supply chain work attribute [7]. The assessment of the supply chain work relationship attributes can be measured with several appropriate methods in its use, one of which is the Supply Chain Operation Reference (SCOR) approach. The SCOR approach model optimizes and compares the most important performance attributes as improvements to support increased supply chain performance [8], then analyzes and projects the stability of the supply chain in accordance with environmental conditions and the application of the performance assessment [9].

\section{Research Method}

The sample is determined purposively, namely respondents who are experts in the field of academics and practitioners of agriculture and similar fields of science. Data collection methods are based on literature study, documentation, observation and questionnaire weighting.

Analytical methods of performance evaluation are 3 process approaches, namely Van Der Vors (supply chain object description) [10], Brainstorming and SCOR-AHP (as a process of weighting performance and problem solving). Meanwhile, the evaluation of indicators is applied One-Way ANOVA (as a measure of the level of risk process and Interpretation Factorials Analysis (as the most important indicator implication).

Emphasizing the problems and objectives of this study, the authors reviewed the pre-survey of 70 farmer respondents throughout Indonesia. The results showed that the variable attributes had met the requirements where the percentage was above $60 \%$ and was declared worthy of research. The main problems studied are how the supply chain structure and how the system implies the stability of supply chain performance in a sustainable manner.

\section{Research Result}


Testing Hypothesis Pathway in Hypothetic Models py1, py2, py3, p31, p32, p21. Path coefficients in the hypothetical model of the study are py1, py2, py3, p31, p32, p21, in determining the magnitude of the path in a hypothetical model the study is obtained by determining the magnitude of the path coefficient value, and then the path coefficient significance test is continued.

\subsection{Instrument Testing}

The test instrument is processed as sterilization data to be analyzed. This test is divided into 3, namely the Credibility Test (as a reference for experts in their field), the Consistency Test (as consistency in each AHP hierarchy), and the Reliability-Validity Test (as an indicator questionnaire test). The results show that all tests are declared significant where the calculated value is in accordance with the specified standard

\subsection{Descriptive Van Der Vorst}

Supply chain management is structured by moving products in the form of materials (commodities) to processed products consumed by consumers. The resource cycle is obtained from supply chain actors, both farmers (seeds and equipment) to collectors/MSMEs (commodity supply). The chain network structure starts with the farmers and then the collectors and SMEs receive the commodity products. Traders will sell with large parties to manufacturers while MSMEs process commodities in small quantities and sell them to the restaurant industry. Then the manufacturing process on a large scale and distributed in packages to consumers.

Farmers' business activities cooperate with providers of vanilla cultivation needs, in addition to agreeing on sales contracts with collectors and MSMEs. Meanwhile, collectors work together in contracts with manufacturers to send / export superior commodities and process them as a mixture of products. The SME industry processes commodities that are sold on a contract basis or freely to the food serving industry or consumers.

\subsection{Analysis SCOR-AHP}

The stages of this analysis process are in 3 hierarchical levels, namely supply chain drivers, supply chain parameters and performance along with supply chain indicators [11] \& [12]. The measurement results based on the statements of 11 respondent experts are presented in Figure 1.

The first level of the planning element has a greater priority while the second hierarchy is the quantity element and the third hierarchy is the reliability element with the derivative of the performance attribute indicator is the accuracy of the quantity of delivery that is more important.

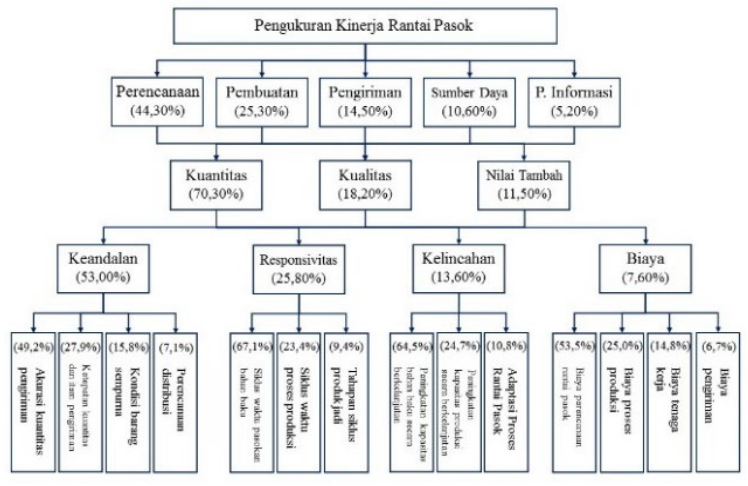


Fig. 1. Weight Results SCOR-AHP

Source: Data processed (2020)

\subsection{Risk Process Process Evaluation}

Referring to research [13] \& [14] that the development of supply chain performance needs to be evaluated on the risks that arise in a supply chain process. Evaluation is assessed through three supply chain actors, namely farmers, collectors, and MSMEs.

Table 5: Estimated Earnings ANOVA

\begin{tabular}{ccc}
\hline Supplier Object & P-Value & Homogeneity \\
\hline Farmers & $0,024^{*}$ & $0,000^{* *}$ \\
Collector & $0,589^{*}$ & $0,790^{* *}$ \\
MSMEs & $0,353^{*}$ & $0,000^{* *}$ \\
\hline
\end{tabular}

*) Significance level $<0,05$

$* *)$ Significance level $<0,05$

Source: Data processed (2020)

The farmer sector is evaluated through a 3-stage planning, cultivation and finalization process. The result of the greatest risk level is in the finalization process $(\mu=645)$ and significant. Meanwhile, the collector evaluation sector is studied through 3 stages, namely planning, procurement and delivery. The results show the procurement process is the greatest level of risk $(\mu=6409)$ and insignificant. In addition, the evaluation of MSME actors is processed through 4 stages of the process, namely planning, procurement, processing and finalization. Where the results show the procurement process has the greatest risk impact $(\mu=5848,67)$ and insignificant.

\subsection{Evaluation Building a Supply Chain Stability Policy Scheme}

Referring to the SCOR-AHP results, we hereby build a supply chain stability policy scheme through 3 schemes. The first scheme is to empower and expand agribusiness in the vanilla field simultaneously [15]; [3]; and [16]. The second scheme is to anticipate and revitalize bioprocesses and standardize agricultural performance [17]; [18]; [19]; and [20]. The third scheme is Stabilizing Selling Prices and Mitigating Post-Harvest Risks on Vanilla Commodities [21][22]. All were evaluated statistically; which indicators were appropriate to be applied by each actor.

Table 6: Estimation Simulation Indicator Schema

\begin{tabular}{lcc}
\hline Selected Indicator & $\sigma^{2}$ & Corr \\
\hline
\end{tabular}




\begin{tabular}{lcc} 
Farmers Sector & \multicolumn{2}{c}{$0,873^{* *}$} \\
P-value & \multicolumn{2}{c}{$0,926^{*}$} \\
Component Transformation Matrix & 22,794 & 0,759 \\
Indicator PT2 & 14,166 & 0,732 \\
Indicator PT3 & 6,785 & 0,690 \\
Indicator PT5 & 2,899 & 0,770 \\
Indicator PT7 & \multicolumn{2}{c}{$0,008^{* *}$} \\
\hline Collector Sector & \multicolumn{2}{c}{$0,874^{*}$} \\
P-value & 37,26 & 0,974 \\
Component Transformation Matrix & \multicolumn{2}{c}{$0,125^{* *}$} \\
Indicator PG1 & \multicolumn{2}{c}{$0,773^{*}$} \\
SME sector & 20,979 \\
P-value & 2,479 \\
Component Transformation Matrix & 0,944 \\
Indicator UK3 & \multicolumn{2}{c}{} \\
Indicator UK6 & \multicolumn{2}{c}{} \\
& \\
\hline
\end{tabular}

*) Positive if $>0.5$

**) Significance if $>0.05$

Source: Data processed (2020)

The implications for the farmer sector of the scheme consist of seven indicators but selected are PT2 and PT3, PT5 and PT7. While the sector of the eight scheme indicators, but the selected indicator is PG1. Besides that, the SME sector out of 8 policy indicators, two indicators were chosen, namely UK3 and UK6. The comparison of correlation and statistical estimation can be seen in table 6 .

\section{Expert Discussion Group}

\subsection{Expert Discussion On Sustainability of Vanilla Commodity Supply Chain Performance}

Referring to the results of the SCOR-AHP weighting, it is concluded that 11 in the relevant fields lead to a supply quantity planning system while also improving the quality and accelerating the production period. Supply chain drivers must prioritize planning as the right first step where every agricultural activity needs to consider a feasibility study of management both resources, energy, costs, and the methods needed when carrying out activities. The experts recommend the supply chain policy scheme so that improvements are made at each stage of the vulnerable supply chain process. The scheme is in accordance with table 6 that is implemented by the three supply chain actors and prioritized indicators that are vulnerable (selected). 
Based on the results of the scheme reference and the conclusion of the discussion, the farmer sector is the indicator as a policy implemented by farmers is to form farmer groups in each region and integrate them (PT1); mobilizing millions of vanilla cultivation through green houses in each region where the selling price gain is concentrated (PT2); dedicating to farmers a tissue culture process that produces quality and accelerated harvests (PT3); dedicating a process of how good and correct cultivation procedures focus on the right growing period of vanilla (PT4); designing a selling price system with a focus on the Break Event Point (BEP) and the full costing method so that there is a balance (PT6); and harvest failure control system by separating premium vanilla commodity based on the type of product processed (PT7).

Meanwhile, the collector sector is based on supply chain criteria and its problems. The indicators of discussion results are integrating the working partners of the collectors' stakeholders by building a reliable coordination system (PG1); implementing an optimal and economic inventory system that controls every time an order is made to farmers (PG2); developing a performance system for collectors by strengthening information systems and transparency of business activities that increase the integrity of business relationships (PG3); controlling the quality control system for commodities that have been supplied by farmers (PG4); designing performance procedures for wholesalers so that the collectors' business management system (PG5) is directed; designing a pricing system that focuses on BEP and Full Costing methods so as to balance marginal commodities (PG6); mitigate the control of commodity defects by categorizing based on class and processing (PG7).

The MSME sector indicator policy is based on the schematic literacy reference and the conclusions of the discussion of experts. So each indicator is to integrate SME stakeholder work partners by prioritizing optimal relations and coordination (UK1); implementing a digital marketing system for processed products so as to increase business revenue (UK2); designing variants of processed vanilla products based on the trend of consumer interest (UK3); designing a control system for the quality control of commodities that have been supplied by farmers, both physically and by commodity categories that affect the quality of processed products (UK4); revitalizing the safety system for commodity production, from processing to packaging that maintains product quality (UK5); maximizing performance by focusing on procedures that guide MSME business management (UK6); designing a product pricing system with a focus on BEP and Full Costing methods so that there is a balance in the percentage of maginal marketing (UK7); mitigating and designing a production failure control system that focuses on processing premium products (UK8).

\subsection{Expert Discussion of Risk Management in Supply Chain Processes}

Referring to the ANOVA test results, the farmer sector at the fermentation stage has a high level of risk processing. Therefore, the focus of control being considered by farmers is to revitalize the fermentation process for vanilla commodity. Based on the control reference [15] and the conclusion of the expert discussion, the first factor is labor, and then the process method and depending on the tools used. So, the labor factor because of discussion of biotechnology, agriculture and government experts suggests gathering and exchanging ideas on past fermentation failures and simple control. While the process method experts recommend a fermentation procedure with a stable temperature by designing a fermentation machine in accordance with the bioprocess procedure. 
In the collector sector, based on statistical test results, the procurement process is riskier. So, the focus of the problem is anticipating price fluctuations and demand. According to the discussion results of agribusiness and supply chain experts, the first control is the intensity of demand in order to create a product line (commodity) based on class level; secondly the availability of commodities by strengthening coordination and proper supply systems; thirdly, price stability by revitalizing sales margins.

The MSME sector is based on the results of the analysis and conclusions of discussions with agribusiness and supply chain experts, the procurement process is riskier. Therefore, the focus of the problem is the mitigation of business procurement activities.

The controls are, first, the factor of price fluctuation by designing digital transactions and equalizing the marginal sales of MSMEs; secondly, material imbalance, namely by cooperating and coordinating with stakeholders and designing an economic supply system; the third is the fulfillment of production capacity, namely by predicting market demand trends, and implementing a continuous production system.

\section{Conclusion}

Drawing conclusions referring to the results and discussion of this research is the first to evaluate the performance of the supply chain for each sector. Therefore, we recommend three schemes, namely agribusiness empowerment, bioprocess revitalization, and risk stabilization and selling price. The three schemes are presented along with the indicators in the three supply chain actors, the results of the simulation of selected indicators of the farmer sector (1 indicator), collectors ( 1 indicator) and MSME ( 2 indicators). The two-supply chain performance risk evaluations in the process are farmers (finalization process), collectors (procurement process) and MSMEs (procurement process). Based on the results of discussions and applied indicators, it is necessary to have technical implementation, especially selected indicators so that the realization of supply chain sustainability.

\section{References}

[1] Saptana, E. Suryan, and E. Darmawati, "Rice Supply Chain Performance , Dynamic and Price Determination In Central Java," Anal. Kebijak. Pertan., vol. 17, no. 1, pp. 39-58, 2019.

[2] A. Raharjo and M. Ridlo, "Mengembalikan Kemasyhuran Vanili Jawa, Emas Hijau Primadona Dunia," Liputan 6, 2019.

[3] L. H. Aramyan, A. G. J. M. O. Lansink, J. G. A. J. Van Der Vorst, and O. Van Kooten, "Performance measurement in agri-food supply chains: A case study," Supply Chain Manag., vol. 12, no. 4, pp. 304-315, 2007.

[4] Kementerian Pertanian, "Mengembalikan Kejayaan Rempah Nusantara, Negara Alokasikan Anggaran 5,5 T," Kementerian Pertanian, 2019.

[5] Bantolo, "Vanili Indonesia Tembus Pasar Eropa dan AS," Bantolo, no. April, 2019.

[6] L. C. Nawangsari and A. H. Sutawijaya, "A framework of green contruction supply chain," Int. J. Supply Chain Manag., vol. 8, no. 1, pp. 162-169, 2019. 
[7] M. De Fazio, "Agriculture and Sustainability of the Welfare: The Role of the Short Supply Chain," Agric. Agric. Sci. Procedia, vol. 8, pp. 461-466, 2016.

[8] A. APICS, "Benchmark your Supply Chain; Close Performance Gaps, American Production and Inventory Control Society," Apics org, no. April, 2019.

[9] F. R. Lima-Junior and L. C. R. Carpinetti, "Quantitative models for supply chain performance evaluation: A literature review," Comput. Ind. Eng., vol. 113, pp. 333-346, 2017.

[10] W. Times, "New Investments Expected To Boost The Vanilla Bean Market at 4.7\% Volume CAGR between 2018-2027," Wikitimes.co.uk, 2019.

[11] C. K. Dissanayake and J. A. Cross, "Systematic mechanism for identifying the relative impact of supply chain performance areas on the overall supply chain performance using SCOR model and SEM," Int. J. Prod. Econ., vol. 201, pp. 102-115, 2018.

[12] M. Moazzam, P. Akhtar, E. Garnevska, and N. E. Marr, "Measuring agri-food supply chain performance and risk through a new analytical framework: a case study of New Zealand dairy," Prod. Plan. Control, vol. 29, no. 15, pp. 1258-1274, 2018.

[13] A. R. Pamungkassari, M. Marimin, and I. Yuliasih, “Analisis Kinerja, Nilai Tambah Dan Mitigasi Risiko Rantai Pasok Agroindustri Bawang Merah,” J. Teknol. Ind. Pertan., vol. 28, no. 1, pp. 61-74, 2018.

[14] B. Gaudenzi and A. Borghesi, "Managing risks in the supply chain using the AHP method," Int. J. Logist. Manag., vol. 17, no. 1, pp. 114-136, 2006.

[15] R. Elizabeth, "Peningkatan Daya Saing Tanaman Pangan Melalui Akselerasi Agroindustri dan Pemberdayaan Kelembagaan Pertanian," J. Pemikir. Masy. Ilm. Berwawasan Agribisnis, vol. 5, no. 2, pp. 379-394, 2019.

[16] S. E. Pratama and H. J. Nadapdap, "Strategi Pengembangan Agribisnis Teh PT Perkebunan Tambi Kabupaten Wonosobo," J. Penelit. Pertan. Terap., vol. 19, no. 1, p. 19, 2019.

[17] N. A. Putri, Z. Najah, Zulmaneri, and T. Hidayat, "Perancangan sop (standar operating procedure) proses produksi amplang di sentra industri kecil hasil pertanian dan kelautan (sikhpk) teritip, balikpapan,” J. Teknol. dan Ind. pangan, vol. 4, no. 2, pp. 57-64, 2019.

[18] S. K. Dermoredjo, "Analisis Kebijakan Pengembangan Padi, Jagung, Dan Kedelai Di Indonesia Dalam Menghadapi Perdagangan Bebas Asean Policy Analysis For Indonesia's Rice, Maize And Soybean Development In Dealing With Asean Free Trade," Anal. Kebijak. Pertan., vol. 12, no. 1, pp. 51-68, 2014.

[19] Z. Abbas, S. M. Khan, J. Alam, S. W. Khan, and A. M. Abbasi, "Medicinal plants used by inhabitants of the Shigar Valley, Baltistan region of Karakorum range-Pakistan," J. Ethnobiol. Ethnomed., vol. 13, no. 1, pp. 1-15, 2017.

[20] L. Nóbrega, P. Gonçalves, P. Pedreiras, and J. Pereira, "An IoT-based solution for intelligent farming," Sensors (Switzerland), vol. 19, no. 3, pp. 1-24, 2019.

[21] K. Suradisastra, "Strategi Pemberdayaan Kelembagaan Petani," Forum Penelit. Agro Ekon., vol. 26, no. 2, p. 82, 2016.

[22] X. Qiao, "Study on the Abnormal Fluctuation of Chinese Agri-Food Price and the Prevention Measures," no. 1, pp. 10-16, 2019. 